\title{
Preortodonciai kortikocízió és szimultán csont augmentáció a bukkális alveoláris dehiszcencia prevenciójában
}

\author{
Esetismertetés
}

\author{
DR. NAGY PÁL*, DR. PÖRZSE VIRÁG** \\ - megosztott első szerzők -
}

\begin{abstract}
Az alábbi esetismertetés célja, hogy bemutassuk egy fogszabályozás előtt álló páciens prevenciós célzatú mútétjét, melylyel a fogtorlódás ortodonciai korrekciója után gyakran kialakuló bukkális csont dehiszcenciát és következményes ínyrecessziót szándékoztunk megelőzni. Esetünkben egy fiatal páciens mandibuláris frontfogain „tunnel” feltárásból végzett kemény- és lágyszöveti minimál invazív rekonstrukciós mútétje, illetve szimultán kortikocíziója után mindkét állcsonton fogszabályozó kezelésben részesült. A fogelmozdulás mértékét az alsó középső metszőfogakon a különböző időpontban készült teleröntgenen mért paramétereiből, míg a bukkális csontfal dimenzióváltozásait a kezelés előtti és utáni CBCT felvételeken hasonlítottuk össze 6 frontfog esetében. A mútét után 1 héttel multibond készülék segítségével kezdődött a fogmozgatás. A rögzített fogszabályozó készülék aktiválását és az ívek cseréjét 2 hetenként végeztük. A nivelláció a kezelés kezdeti szakaszában kis erőket biztosító ívszekvenciának köszönhetően 20 hét alatt zajlott le, míg a fogszabályozó készülék levétele után a magmaradt bukkális csontfalvastagságok a kiindulásival összehasonlítható értéket mutattak. Radiológiailag igazolható jelentős vertikális csontvesztés nem következett be. A jelen esetben alkalmazott eljárás biztonságosnak ígérkezhet a fogszabályozás parodonciumot érintő szövődményeinek megelőzésében.
\end{abstract}

Kulcsszavak: kortikocízió, csontaugmentáció, ortodoncia, fogszabályozás, multibond

\section{Bevezetés}

A fogszabályozó kezelések indikációi között gyakran szerepel a fogívszükület következményes fogtorlódással. Amennyiben kompenzatorikus extrakció nélkül szeretnénk a torlódást megszüntetni, akkor ezt végezhetjük az állcsontok transzverzális tágításával, ha a hiba az adott állcsont szűkületéből adódik, illetve nyerhetünk helyet a frontfogak protrúziójával is. Állatkísérletekből és humán klinikai vizsgálatokból tudjuk, hogy a fogszabályozó készülék által létrehozott orovesztibuláris fogelmozdulást nem követi a kortikális csont, így a fog kiszabályozása a csontos fogmederből alveoláris dehiszcenciához vezet [6, 22]. A csontos bázisát vesztett marginális gingiván következményes manifeszt ínyrecesszió alakulhat ki trauma vagy gyulladásos okból kifolyólag [9, 17]. Irodalmi adatok szoros összefüggést mutattak ki a frontfogak labiolingvális inklinációja és az alveoláris dehiszcencia, illetve ínyrecesszió frekvenciája között [2]. A fogak túlzott labiális inklinációja esetében a mandibuláris frontfogak nagyobb mértékű vertikális és horizontális csontveszteséget mutattak a bukkális alveoláris oldalon, mint a maxillán [18]. A kialakult ínyrecesszió korszerú mukogingivális plasztikai mútétekkel ugyan korrigálható, de kivitelezése sebészileg technika-szenzitív, autogén graft használata esetén traumás a páciens számára, és a hosszú távú stabilitását illetően az irodalmi adatok ellentmondásosak [4].

A szakirodalomban már viszonylag régóta fellelhetők mútéttel kombinált olyan fogszabályozó kezelések, melyek föleg az állcsontok frontterületén végeznek csontaugmentációt szimultán szelektív dekortikalizációval egybekötve (PAOO technika: „periodontally accelerated osteogenic orthodontic”, vagy más néven „augmented corticotomy"). Ezek célja a bukkális csontfal megvastagítása, ezáltal a posztterápás stabilitás megnövelése, illetve a fogszabályozás határainak kiterjesztése és a kezelés idejének lecsökkentése [23, 29]. A későbbi potenciális ínyrecesszió megelőzhető, ha a fogakat az augmentált csontba mozgatjuk bele, és a megnövelt íven nem szabályozzuk őket túl. Számos lebenytechnikát és csontpótlásra használatos anyagot tart számon a szakirodalom [1, 29]. A legtöbb esetben a szerzők teljes vastag nyeles lebenyeket használtak, míg a graft alkalmazását illetően a legtöbb adat a xenograftok mellett szól, melyek beszerzése és használhatósága egyszerü, nem felszívódó tulajdonságuk miatt pedig ideálisak [28]. A fogszabályozás által kiváltott csont remodelláció a csontpótolt terület jobb átépüléséhez vezethet, ami a kezelés befejeztével egy stabil kortikális réteg kialakulását igazolja CBCT vizsgálatok és állatkísérletek eredményeit alapul véve $[5,19]$. Saját humán hisztológiai 
eredményeinkből tudjuk, hogy a xenografttal augmentált terület - ez a fogmozgatás szempontjából nyomási oldalnak felel meg - az oszteoklasztok hatására gyulladásmentes reszorpciót és következményes de novo csontképzést mutat, ami igazolja a xenograftok biztonságos remodellációját hasonló körülmények között [24]. A csont augmentációs mútét során használt dekortikalizáció (kortikotómia) a műtött terület jobb vérellátását szolgálja. A kortikotómia másik fontos hatása a „regionálisan felgyorsult fenomén" (RAP: regional acceleratory phenomenon), ami a sebészi trauma során felszabaduló proinflammatorikus citokinek és növekedési faktorok által megnövelt csont remodellációs kapacitásnak tulajdonítható $[10,11]$. Egyes közlemények szerint az RAP jelenség hatására a fogszabályozó kezelés ideje rövidülhet a felgyorsult csontátépülésnek köszönhetően [20]. Az elmúlt két évtizedben számos kortikotómiás mútétet leírtak, melyeknek technikai kivitelezése jelentősen eltér, de végeredményképpen mindegyik mútéttípus a fogszabályozó kezelés által kiváltott remodelláció felgyorsulását célozza. Az irodalmi adatok azonban a felgyorsulás mértékére vonatkozóan ellentmondásosak. Az RAP hatás maximumát az első két hónapban éri el, míg hatása körülbelül négy hónap [26]. Ezalatt a fogszabályozó készülék aktiválási gyakorisága növelhető (1-2 hetente), ezáltal a nivellációs szakasz is felgyorsulhat. Azonban a teljes fogszabályozási időt tekintve, a kezdeti stádium lerövidült kezelési idejének szignifikanciája már eltűnni látszódik [16].

A modern PAOO technikák a posztoperatív morbiditás csökkentésére irányulnak, törekedve a minimálinvazív lebenyek használatára, illetve a kortikotómia során eltávolított csont mennyiségének csökkentésére és atraumatikusságára (pl. ultrahangos piezosebészet alkalmazása, elkerülve a parodontális ligamentumok és egyéb potenciális idegek sérülését) [7]. Az utóbbi, úgynevezett kortikocíziós minimálinvazív mütétek fogszabályozási időt redukáló hatásosságáról kevés kontrollált klinikai adat áll rendelkezésre [15]. Jelen esetbemutatásunk célja, hogy egy megfelelő indikációjú fogszabályozó kezelés előtt álló pácienst a PAOO modern kezelési elveit célzó multidiszciplináris kezelésben részesítsük. Elsődleges célkitǔzésünk megvizsgálni, hogy a fogszabályozó kezelés végére az augmentáció hatására kialakult bukkális csont mennyisége megfelelő, illetve összehasonlítható-e a kiindulási értékekkel, továbbá értékeljük a fogelmozdulás sebességét a nivellációs kezelési fázisban.

\section{Vizsgálati anyag és módszerek}

A bemutatott esetet a Semmelweis Egyetem Fogászati és Szájsebészeti Oktató Intézet, Fogszabályozási Osztályára érkező páciensei közül választottuk ki. Önkéntesünk résztvevője egy folyamatban levő randomizált kontrollált klinikai vizsgálatnak (etikai engedély száma: SE-TUKEB 16/2019), nagykorú törvényes képviselője (szülő) írásos beleegyezését adta a kezelésbe. A 17 éves, jó általános egészségi és parodontális állapottal rendelkező férfi páciensnél az ortodonciai diagnosztikai eljárásokat követően dentális eredetű mélyharapást (overbite mértéke 3,5 mm), alsó középvonal eltolódást és a mandibula frontfogai területén $6 \mathrm{~mm}$ helyhiányt diagnosztizáltunk (1. kép). A páciens szkeletálisan és dentálisan is Class I relációval bírt. A kezelési terv magába foglalta az anterior régió fogtorlódásának megszüntetését a fogak protrúziója által, az alsó dentális középvonal rendezését a felsőhöz, és a dentális eredetű mélyharapás korrigálását is. Alternatív kezelési tervként szóba jöhetett volna extrakciós terápia is, de ezt a páciens és szülei határozottan elutasították. Célunk eléréséhez felső és alsó rögzített (multibond) készüléket használtunk. A fogtorlódás feloldásához szükséges protrúzió mértéke felvetette a problémát, hogy a fogat kimozgatjuk az alveólus „csontos borítékjából” a bukkális oldalon. Ennek elkerülése végett az alábbi PAOO elveit, illetve protokollját követő preortodonciai mútétet végeztük a Semmelweis Egyetem Parodontológiai Klinikáján:

Helyi érzéstelenítésben (Ultracain DS Forte 4\%) három darab vertikális segédmetszést ejtettünk a mandibula bukkális oldalán, egyet a középvonalban, míg kettőt a szemfog és az első kisörlő között. A segédmetszés $3 \mathrm{~mm}$ távolságban kezdődött a papilla csúcsától, és minimálisan túlhaladta apikálisan a határoló fogak gyökércsúcsát. Először a mukogingivális junkciótól apikálasan egy félvastag, szupraperioszteális, majd a marginális ínyszélig és a papilla bázisáig terjedő szubperioszteális alagút lebenyt preparáltunk tunnel-kések (Deppeler SA, Rolle, Svájc) segítségével (2. kép). A vertikális segédmetszések összekötésével oly módon mobilizáltuk a perioszteumot az alveoláris csontról, hogy sem a marginális ínyszélt, sem a papillákat nem metszettük át. Ez lehetővé tette a lebeny keringésének jobb megtartását [30]. Az interdentális szeptumok helyén piezosebészi motor (VarioSurg 3, NSK, Tochigi Japán) segítségével kortikozíciós (piezocízió) bemetszéseket ejtettünk (3. kép). A csontbemetszések csak apikokoronális kiterjesztésüek voltak, melyeknek a mélysége épphogy túljutott a kortikális csonton. A vertikális segédmetszések helyén egyenes, míg a többi fogközben hajlított fejü sebészi kést használunk, hogy könnyedén beférjünk a „tunnelizált” lebeny alá (SG1, SG14R, SG14L fejek, NSK, Tochigi, Japán). A keményszöveti augmentációhoz a Choukroun protokoll szerint vérlemezkékben és leukocitákban gazdag fibrinből (A-PRF) és xenograftból (Cerabone ${ }^{\circledR}$ csontpótló, Botiss Biomaterials $\mathrm{GmbH}$, Zossen, Németorzság) előre elkészített „sticky bone”-t használtunk (A-PRF membrán+ xenograft+ A-PRF folyadék) [13, 14, 27]. Ebböl 2 darab kb. $15 \mathrm{~mm}$ hosszú (középvonaltól 13 fogig), $10 \mathrm{~mm}$ széles (gyökérhossznak megfelelö) és $2 \mathrm{~mm}$ vastag (tervezett csontvastagítás mértéke) blokkokat képeztünk (4. kép), melyeket behelyeztünk a jobb- és baloldalra a szubperioszteális alagútszerú réteg alá, miközben megpróbáltuk koronális irányba tömöríteni. A felszínesebb rétegbe lágyszöveti vastagítást és gyógyulást elősegítő 

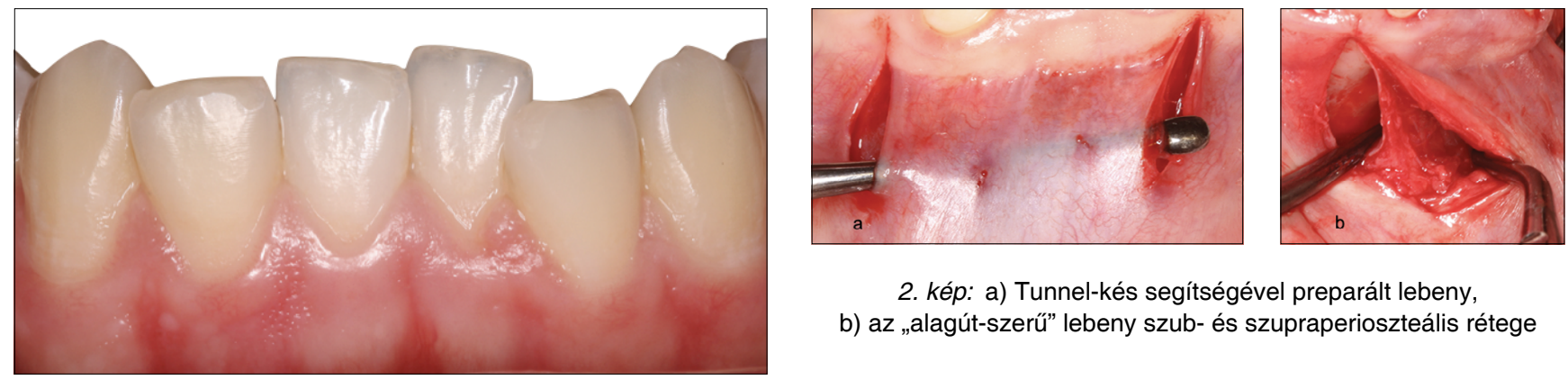

2. kép: a) Tunnel-kés segítségével preparált lebeny,

b) az „alagút-szerü” lebeny szub- és szupraperioszteális rétege
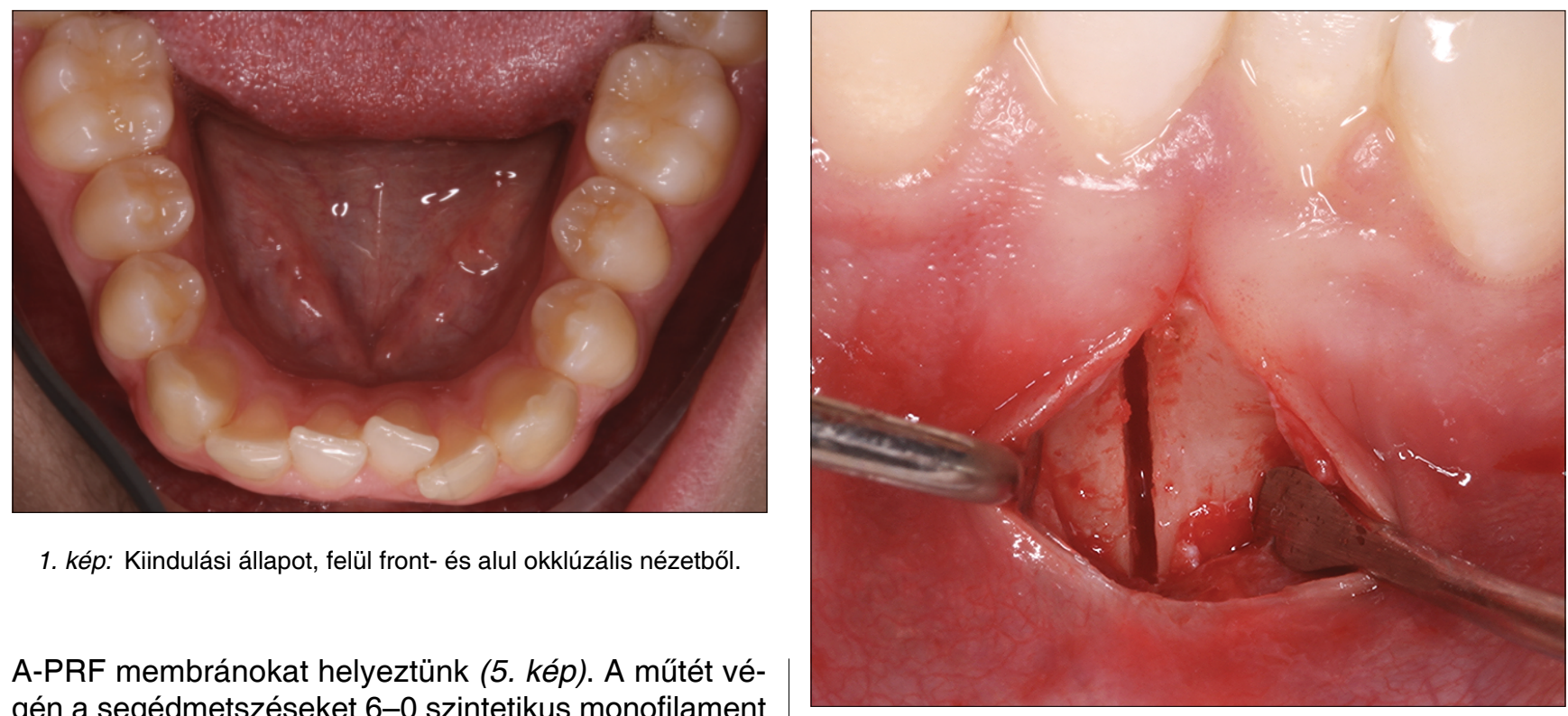

A-PRF membránokat helyeztünk (5. kép). A mütét végén a segédmetszéseket $6-0$ szintetikus monofilament varróanyaggal (Dafilon, BBraun, Németország) egyesítettük. A mútétet követően a páciens antibiotikum terápiában részesült (amoxicillin + klavulánssav $/ 625 \mathrm{mg}$ X3/ 3 napig), kiegészítve a panaszok múlásáig nem szteroid gyulladáscsökkentővel (diclofenac 50 mg X3). Lokális kemoprofilaxist (chlorhexidin 0,2\%) ajánlottunk napi egyszer a 7 . napon esedékes varratszedésig.

A páciens a varratszedés napján fix multibond típusú fogszabályozó készüléket kapott (OmniArch, Roth előirat, 0,022 slot, Dentsply Sirona, York, USA), melyhez kéthetes aktiválási szakaszokat írtunk elő. A fogmozgatáshoz használatos ívszekvencia az alábbi volt: először egy kerek profilú, 0,014-es átmérőjū NiTi ívvel kezdtük, melyet négy héttel később egy 0,016-os NiTi ív követett. A 3. hónapban a páciensnek egy 0,016 ×0,022os Niti ívet kötöttünk be, melyet a 4. hónapban egy 0,020 $\times$ 0,020-as Bioforce ívre cseréltünk (GAC Dentsply Sirona, York, USA). A kezelés végül egy $0,019 \times 0,025$-ös, majd pedig egy $0,021 \times 0,025$-ös acélívvel zárult. A páciens a rögzített készülék eltávolítása után az alsó fogívére fix retainert kapott.

A fogelmozdulás és a bukkális csont dimenzióinak változására az alábbi paramétereket regisztráltuk: a kiindulási és a nivellációs szakasz befejezésekor (PAR index szerinti 0-s stádium elérésekor [25]) készült teleröntgen felvételeken elemeztük a középső metszőfogak elmozdulásának mértékét a nivellációra fordított idő függvényében ( $\Delta$ IMPA és $\Delta$ T/nivellációs idő), illetve

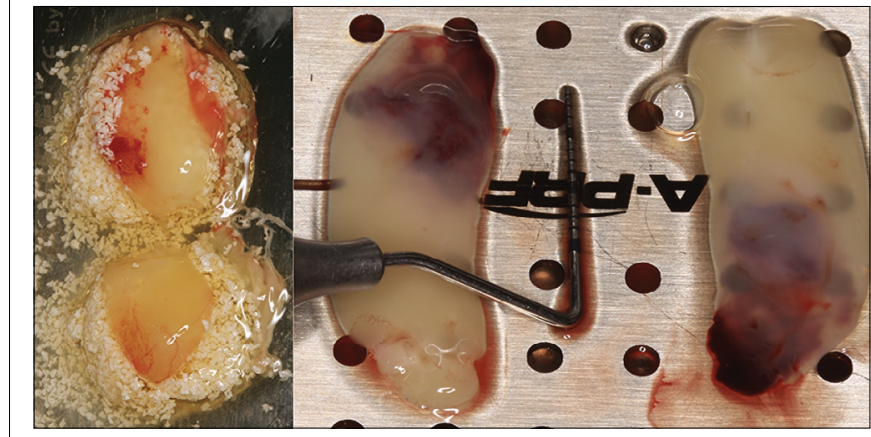

4. kép: Az augmentációhoz használt anyagok: a) „sticky bone” b) A-PRF membrán
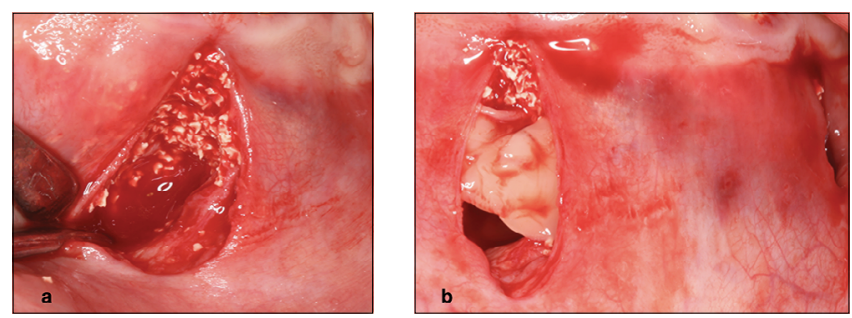

5. kép: a) A perioszteum alá behelyezett „sticky bone” b) szupraperioszteálisan behelyezett A-PRF membrán 


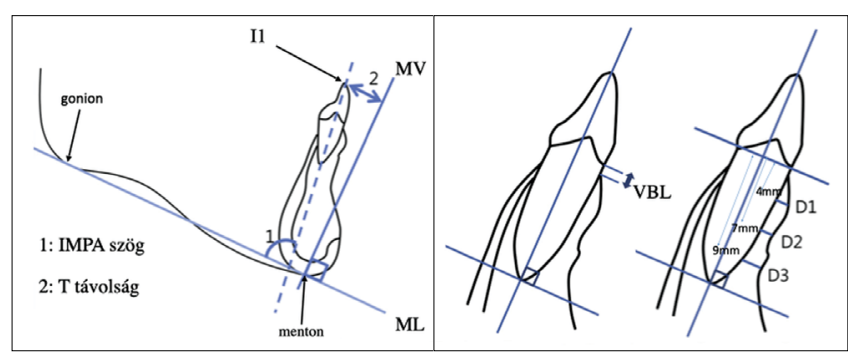

6. kép: IMPA szög: az alsó 1-es tengelye

(gyökércsúcs és incizális ponton húzott érintő)

és a mandibuláris alapsík ( $M L$ : Menton-gonion referencia pontokra fektetett érintő) által bezárt szög $\left(^{\circ}\right)$.

$T$ távolság: az alsó középső metsző incizális pontjának (I1) az MV (a Menton vonalában az ML vonalra húzott merőleges) vonaltól mért merőleges, azaz legrövidebb távolsága $(\mathrm{mm})$. VBL: vertikális csont magasság

(a CEJ és a labiális alveoláris csont legkresztálisabb széle között mért távolság a koronális metszeten mérve).

Csontvastagság (D1, D2, D3): bukkális alveoláris csontvastagság a szagittális síkban a koronális-D1, a középső-D2 és az apikális harmadban-D3 mérve

(a bukkális és linguális CEJ pontokat összekötő referencia vonaltól 4,7, illetve $9 \mathrm{~mm}$ távolságban).

a mandibula 6 frontfogánál CBCT felvételen megmértük a kezdeti és a végállapot (fogszabályozó levétele) bukkális vertikális csontszint ( $\triangle \mathrm{VBL}$ ) és a bukkális horizontális csontvastagság változását. Ez utóbbit a zománccement határtól számítva apikokoronálisan 3 szinten mértük Lund és mtsai ajánlásait figyelembe véve, melyek a gyökér reprezentatív három harmadában szolgálnak eredményül $(\Delta \mathrm{D} 1, \Delta \mathrm{D} 2, \Delta \mathrm{D} 3)$ [21]. A regisztrált paramétereket képletesen az 6. kép szemlélteti [1].

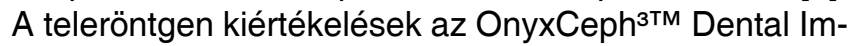
aging (Chemnitz, Germany) szoftver segítségével, míg a $15 \mathrm{~cm} \times 8 \mathrm{~cm}$ térfogatú mandibula CBCT kiértékelése a Vatech Pax REVE3D (Gyeonggi-do, Korea) szoftver használatával történtek.

\section{Eredmények}

A mútéti terület gyógyulása zavartalan volt. A fogszabályozó kezelés 8 hónapig tartott, melyből a nivellációs fázis 20 hetet vett igénybe. A kezelés végére a klinikai és röntgenvizsgálat során káros mellékhatást a fogak gyökerére és a parodoncium állapotára vonatkozóan nem tapasztaltunk. Az elért eredményt a pácienssel egyetértésben esztétikailag és funkcionálisan is megfelelönek találtuk (7. kép).

A mandibuláris 6 frontfog kiindulási és végállapot CBCT méréseit a bukkális csont dimenzióira vonatkozóan a táblázat, míg a koronális metszeteket egy fog esetében megfelelő nagyításban a 8 . kép mutatja. A végállapot $\mathrm{CBCT}$ felvételein vékony, de markáns bukkális alveoláris csontfal rajzolatai jól megfigyelhetők voltak. A csontfalak vastagságai a különböző apikokoronális magasságokban jól korreláltak a kiindulási értékekkel.
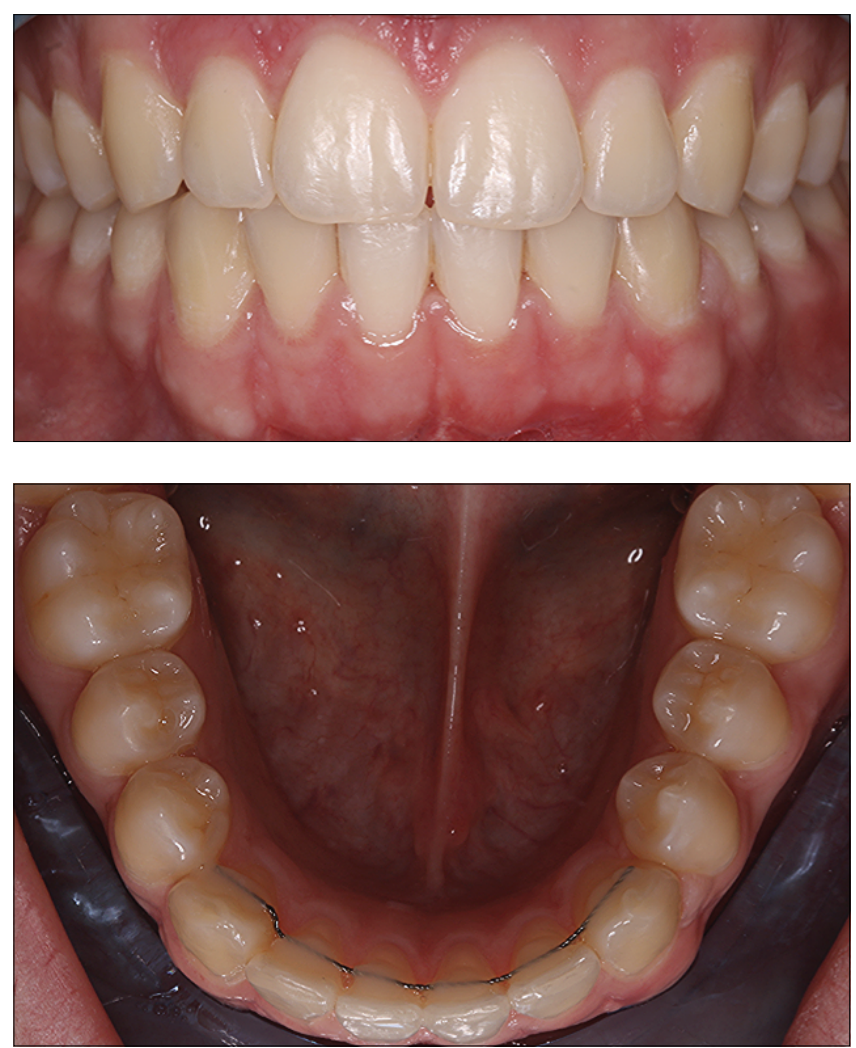

7. kép: A fogszabályozás végére elért állapot front- és okkluzális nézetből.

Látható a stabil, ínyrecesszió nélküli parodontális, illetve a funkcionálisan és esztétikailag is elfogadható fogazati állapot.

A 31 fog apikális harmadában mért értéken kívül a vastagság paraméterei a végállapot során nemhogy nem mutattak veszteséget, még minimálisan nőttek is $(\triangle D 1$, $\Delta \mathrm{D} 2, \Delta \mathrm{D} 3)$. Vertikális csontmagasság vesztességet $(\Delta \mathrm{VBL})$ csak a 31 és a 33 fogak esetében tapasztaltunk, melyek mértéke nem haladta meg a 0,4 mm-t. Bizonyos esetekben a vertikális csontnívó jelentős növekedést mutatott, a 43 fognál elérte az $1,2 \mathrm{~mm}$-t is. A kefalomet-

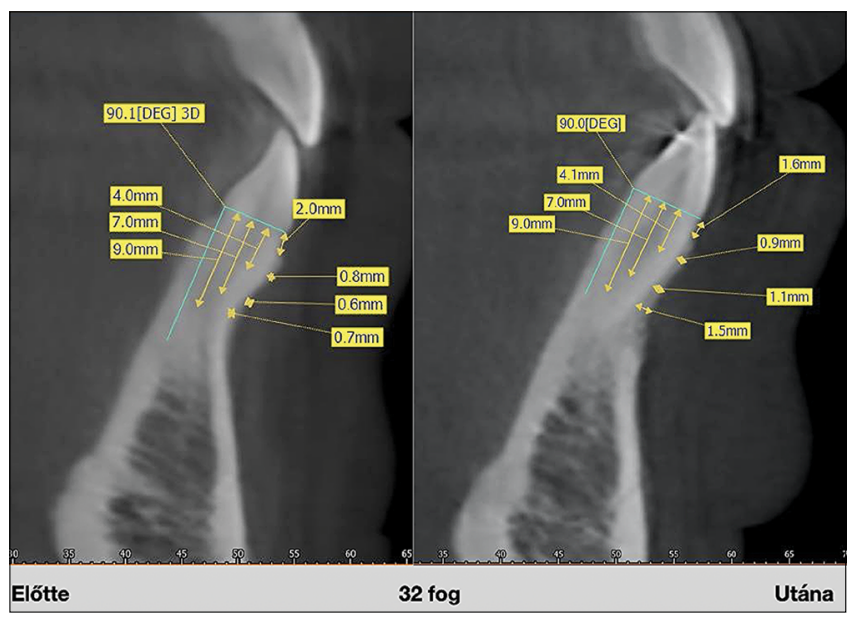

8. kép: A kiindulási (bal oldal) és a végállapot (jobb oldal) CBCT koronális metszete 32 fog esetében. 
A bukkális csontfal dimenziói a kiindulási $(K)$ és végállapot $(V)$,

illetve a kettő közötti változás ( $\Delta$ : végállapot-kiindulás) alkalmával.

(A rövidítéseket lásd az 1. ábránál, illetve a rövidítések jegyzékénél.)

\begin{tabular}{|c|c|c|c|c|c|c|}
\hline Fogak száma & $\mathbf{4 3}$ & $\mathbf{4 2}$ & $\mathbf{4 1}$ & $\mathbf{3 1}$ & $\mathbf{3 2}$ & $\mathbf{3 3}$ \\
\hline VBL-V & $0,6 \mathrm{~mm}$ & $1,3 \mathrm{~mm}$ & $1,4 \mathrm{~mm}$ & $1,9 \mathrm{~mm}$ & $1,6 \mathrm{~mm}$ & $2,0 \mathrm{~mm}$ \\
\hline D1-V & $0,3 \mathrm{~mm}$ & $0,9 \mathrm{~mm}$ & $1,2 \mathrm{~mm}$ & $1 \mathrm{~mm}$ & $0,9 \mathrm{~mm}$ & $0,6 \mathrm{~mm}$ \\
\hline D2-V & $0,5 \mathrm{~mm}$ & $0,7 \mathrm{~mm}$ & $1 \mathrm{~mm}$ & $0,7 \mathrm{~mm}$ & $1,1 \mathrm{~mm}$ & $0,8 \mathrm{~mm}$ \\
\hline D3-V & $1,1 \mathrm{~mm}$ & $1 \mathrm{~mm}$ & $1,2 \mathrm{~mm}$ & $0,7 \mathrm{~mm}$ & $1,5 \mathrm{~mm}$ & $1 \mathrm{~mm}$ \\
\hline
\end{tabular}

\begin{tabular}{|c|c|c|c|c|c|c|}
\hline Fogak száma & $\mathbf{4 3}$ & $\mathbf{4 2}$ & $\mathbf{4 1}$ & $\mathbf{3 1}$ & $\mathbf{3 2}$ & $\mathbf{3 3}$ \\
\hline$\Delta$ VBL & $-1,2 \mathrm{~mm}$ & $-0,7 \mathrm{~mm}$ & $-0,2 \mathrm{~mm}$ & $0,4 \mathrm{~mm}$ & $-0,4 \mathrm{~mm}$ & $0,4 \mathrm{~mm}$ \\
\hline$\Delta \mathbf{D} \mathbf{1}$ & $0,0 \mathrm{~mm}$ & $0,1 \mathrm{~mm}$ & $0,0 \mathrm{~mm}$ & $0,0 \mathrm{~mm}$ & $0,1 \mathrm{~mm}$ & $0,2 \mathrm{~mm}$ \\
\hline$\Delta \mathbf{D 2}$ & $0,1 \mathrm{~mm}$ & $0,1 \mathrm{~mm}$ & $0,1 \mathrm{~mm}$ & $0,3 \mathrm{~mm}$ & $0,5 \mathrm{~mm}$ & $0,1 \mathrm{~mm}$ \\
\hline$\Delta \mathbf{D} 3$ & $0,2 \mathrm{~mm}$ & $0,3 \mathrm{~mm}$ & $0,3 \mathrm{~mm}$ & $-0,3 \mathrm{~mm}$ & $0,8 \mathrm{~mm}$ & $0,3 \mathrm{~mm}$ \\
\hline
\end{tabular}

riai analízis során a középső metszőfogak elmozdulását jelző paraméterek közül az IMPA szög növekedése $6,4^{\circ}$, míg a T távolság csökkenése $3,5 \mathrm{~mm}$ volt. Az egységnyi időre számolt fogelmozdulás mértéke ( $\triangle$ IMPA és $\Delta$ T/nivelláció hetei) a nivelláció szakaszában $0,32 \%$ hét, illetve $0,175 \mathrm{~mm} /$ hét értékeket mutatott.

\section{Megbeszélés}

A potenciálisan megnövelt alveoláris csont térfogata és egy intaktabb parodoncium létrehozása a bukkális csont dehiszcenciák és következményes ínyrecessziók kialakulásának csökkenését eredményezheti. A kezelési idő lerövidülése, a fogmozgatás határainak kiterjesztése, valamint a kompenzatorikus extrakciók elkerülése mind olyan tényezők, melyek a PAOO technikák gyors elterjedéséhez vezettek [3]. A minimálinvazív sebészi („tunnel-lebeny”) eljárások, kiegészítve atraumatikusabb piezosebészi múszerekkel végzett múveletekkel, a beavatkozásokat még elfogadhatóbbá teszik a betegek és az orvosok számára egyaránt, köszönhetően a csökkent posztoperatív morbiditásnak [7].

Az általunk közölt eset célja egy elöbb említett komprehenzív kezelés bemutatása, melyet egy aktuálisan folyó kontrollált klinikai vizsgálatból ragadtunk ki. A kezelési eljárás újszerúsége a Choukroun által kifejlesztett „sticky bone” graft anyag használata, melyet jelenlegi tudásunk szerint még nem publikáltak hasonló sebészi protokoll és klinikai indikáció során. Az A-PRFet tartalmazó „ragacs csont” olyan növekedési faktorok (BMP-2, BMP-7, PDGF, VEGF, TGF stb.) autológ forrása, melyek fontos szerepet játszanak a csontképződés, angiogenezis és a korai sebgyógyulás folyamataiban egyaránt $[8,12]$. A közismert biológiai hatása mellett további előnye lehet a mütét közbeni egyszerübb felhasználhatóság, hisz az „egybekötött” graft anyag nemcsak könnyebben behelyezhető a „tunnel-lebeny” alá, de a partikulumok szétszóródása is könnyebben kontrollál- ható, mint hasonló csontpótló anyagokat önmagukban használva.

$A z$ elsődleges célkitűzés során vizsgált paraméter a CBCT-n mért bukkális csontfal dimenzióváltozása. Megállapíthatjuk, hogy a különböző magasságokban mért végállapot csontvastagság értékei hasonlóságot mutatnak a kiindulási értékekkel, és legtöbb esetben meghaladják a kívánatos $0,5 \mathrm{~mm}$-es vastagságot, mely alapjául szolgálhat a gingiva megfelelő hosszú távú alátámasztásának. Az eredményeket annak a tükrében kell vizsgálni, hogy a fogmozgatás során a fogak az eredeti fogívhez képest egy bukkálisabb pozícióba kerültek. A középső metszőfogak incizális élénél mérve ez megközelítőleg egy 3,5 mm-es protrúziós elmozdulást jelentett, míg az említett fogak körülbelül $6^{\circ}$-al dőltek labiális irányba. Ha feltételezzük, hogy az augmentált csontba történő fogmozgás egy gyulladásmentes reszorpciót indít el, mely érinti a xenograft szemcséket is, akkor a pótolt csont közvetlen fog felé néző része remodellálódik, míg a külső réteg intakt marad, és szemcséit potenciálisan újonnan képződött csont veszi körül. Az eredmény megfelelőnek tekinthető, amennyiben ennek a megmaradt csontfalnak a vastagsága jól korrelál a kiindulási értékkel. A VBL értékeket elemezve elmondható, hogy két fog esetében 0,4 mm-el nőtt a marginális csont távolsága a CEJ-től. Ez betudható a protrúzió során bekövetkezett posztoperatív recessziónak, illetve a nem megfelelő mennyiségű koronális graftolásnak is, de okozhatja a fogszabályozó készülék által kiváltott esetleges minimális extrúzió is. A többi 4 fog esetében a $\Delta V B L$ csökkenése valószínúleg az ortodonciai intrúzónak volt köszönhető. A kapott eredményeket azonban kritikával kell értékelni, ugyanis a CBCT szoftverben a kalkulált értékek tized milliméterei nehezen mérhetők. A jelentős mérési hibalehetőség statisztikai átlagszámítás hiányában téves konklúzió felállításának forrása lehet. Mindazonáltal leszögezhető, hogy az adatok bárminemü statisztikai kiértékeléséhez nagyobb esetszám lenne szükséges. 
A vizsgálat során értékeltük a fogelmozdulás sebességét a nivellációs kezelési fázisban. Összehasonlítási alapunk arra vonatkozóan nincs, hogy hasonló klinikai esetben a fogszabályozást kortikotómia nélkül végezve változik-e a nivellációra fordított idő, ezért csak önkényesen tudjuk megállapítani, hogy a nivelláció során eltelt 20 hét egy hasonló fogtorlódás esetében nem túnik sokkal rövidebbnek egy átlagos 22-26 héthez viszonyítva. Az általunk használt viszonyítási szám, amely az egységnyi idő alatt történt fogelmozdulást reprezentálja $\left(0,32^{\circ} /\right.$ hét, illetve $0,175 \mathrm{~mm} /$ hét), nem mutat gyorsabb fogelmozdulást, mint egy kortikotómia nélküli szabályozás. Egyes szerzők szerint azonban az RAP hatásnak köszönhetően ilyen esetekben egy rapidabb, kevesebb ívet magába foglaló ívszekvencia is sikeresen alkalmazható. A korábbi szakaszban a lehető legvastagabb rugalmas ív bekötésével, és egyes ívméretek kihagyásával a szabályozás időtartama káros mellékhatások kiváltása nélkül (jelentős gyökér reszorpció, pulpa károsodás) tovább rövidíthető [3].

Összességében konstatálhatjuk, hogy az általunk alkalmazott kezelés megbízható alternatíva lehet hasonló problémával rendelkező páciensek esetében, azonban az eredmények sikeres interpretálásához további jól megtervezett klinikai vizsgálatok szükségesek. Véleményünk szerint a kezelést végző fogorvosoknak a fogszabályozás előtti csontviszonyok CBCT elemzésére, a fogmozgatás pontos megtervezésére, és ez által az ínyrecessziók prevenciójára a jövőben nagyobb klinikai hangsúlyt kellene fektetni.

\section{Rövidítésjegyzék}

\section{A-PRF: $\quad$ Advanced-Platelet Rich Fibrin}

(,fejlett” vérlemezkékben gazdag plazma)

BMP: $\quad$ Bone Morphogenetic Protein (csont morfogenikus fehérje)

CBCT: $\quad$ Cone Beam Computed Tomography

CEJ: Cemento-Enamel Junction

(zománc-cement határ)

D1, D2, D3: bukkális csontvastagságok különböző apiko-koronális magasságban mérve

11: $\quad$ alsó középső metsző incizális pontja

IMPA: alsó középső metsző tengelye és ML vonal által bezárt szög

K: $\quad$ kiindulási

ML: $\quad$ Mandibuláris alapsík (Menton-gonion referencia pontokra fektetett érintő)

MV: $\quad$ a Menton vonalában az ML vonalra húzott merőleges

NiTi: $\quad$ Nikkel-titán

PAOO: $\quad$ Periodontally Accelerated Osteogenic Orthodontic („parodontálisan felgyorsított csontpótlással egybekötött ortodoncia")

PAR: $\quad$ Peer Assessment Rating (kiértékelés fogszabályozás eredményének értékeléséhez)

PDGF: $\quad$ Platelet Derived Growth Factor (vérlemezke eredetű növekedési faktor)

RAP: Regional Acceleratory Phenomenon („regionálisan felgyorsult fenomén”)

SE-TUKEB: Semmelweis Egyetem - Tudományos és Kutatásetikai Bizottság

T: $\quad$ I1 pont MV-től mért legrövidebb távolsága

TGF: $\quad$ Transforming Growth Factor (transzformáló növekedési faktor)

V: $\quad$ végállapot

VBL: Vertical Bone Length (vertikális csont magasság)

VEGF: Vascular Endothelial Growth Factor (vaszkuláris endotheliális növekedési faktor)

\section{Irodalom}

1. Ahn HW, Seo DH, Kim SH, Park YG, Chung KR, Nelson G: Morphologic evaluation of dentoalveolar structures of mandibular anterior teeth during augmented corticotomy-assisted decompensation. Am J Orthod Dentofacial Orthop 2016; 150: 659-669. https://doi.org/10.1016/j.ajodo.2016.03.027

2. Artun J, Krogstad O: Periodontal status of mandibular incisors following excessive proclination. A study in adults with surgically treated mandibular prognathism. Am J Orthod Dentofacial Orthop 1987; 91: 225-232. https://doi.org/10.1016/0889-5406(87)90450-1

3. Bell WH, Finn RA, Buschang PH: Accelerated orthognathic surgery and increased orthodontic efficiency: a paradigm shift. $J$ Oral Maxillofac Surg 2009; 67: 2043-2044. https://doi.org/10.1016/ j.joms.2009.07.005

4. Cairo F, Nieri M, Pagliaro U: Efficacy of periodontal plastic surgery procedures in the treatment of localized facial gingival recessions. A systematic review. J Clin Periodontol 2014; 41: S15 44-62. https://doi.org/10.1111/jcpe.12182

5. Coscia G, Coscia V, Peluso V, Addabbo F: Augmented corticotomy combined with accelerated orthodontic forces in Class III orthognathic patients: morphologic aspects of the mandibular anterior ridge with cone-beam computed tomography. J Oral Maxillofac Surg 2013; 71: 1760. e1-9. https://doi.org/10.1016/j.joms.2013. 04.022

6. Danz JC, Bibby BM, Katsaros C, Stavropoulos A: Effects of facial tooth movement on the periodontium in rats: a comparison between conventional and low force. J Clin Periodontol. 2016; 43: 229-237. https://doi.org/10.1111/jcpe.12505

7. Dibart S, Sebaoun JD, Surmenian J: Piezocision: a minimally invasive, periodontally accelerated orthodontic tooth movement procedure. Compend Contin Educ Dent 2009; 30: 342-344, 346, 348-350.

8. Dohan DM, Choukroun J, Diss A, Dohan SL, Dohan AJ, Mouhy J, et al: Platelet-rich fibrin (PRF): a second-generation platelet concentrate. Part II: platelet-related biologic features. Oral Surg Oral Med Oral Pathol Oral Radiol Endod 2006; 101: e45-50. https:// doi.org/10.1016/j.tripleo.2005.07.009

9. FINKLEMAN SA, BAYIRLI B: Prevalence of gingival recession after orthodontic tooth movements. Am J Orthod Dentofacial Orthop 2018; 153: 614. https://doi.org/10.1016/j.ajodo.2018.03.003

10. Frost HM: The biology of fracture healing. An overview for clinicians. Part I. Clin Orthop Relat Res 1989; 248: 283-293. https:// doi.org/10.1097/00003086-198911000-00045

11. Frost HM: The biology of fracture healing. An overview for clinicians. Part II. Clin Orthop Relat Res 1989; 248: 294-309. https:// doi.org/10.1097/00003086-198911000-00046 
12. Fujioka-Kobayashi M, Miron RJ, Hernandez M, Kandalam U, Zhang $Y$, Choukroun J: Optimized platelet-rich fibrin with the low-speed concept: growth factor release, biocompatibility, and cellular response. J Periodontol 2017; 88: 112-121. https://doi.org/10.1902/ jop.2016.160443

13. Ghanaati S, Booms P, Orlowska A, Kubesch A, Lorenz J, RutKOWSKI J, et al: Advanced platelet-rich fibrin: a new concept for cell-based tissue engineering by means of inflammatory cells. J Oral Implantol 2014; 40: 679-689. https://doi.org/10.1563/aaid -joi-D-14-00138

14. Giannini S, Cielo A, Bonanome L, Rastelli C, Derla C, Corpaci F, et al: Comparison between PRP, PRGF and PRF: lights and shadows in three similar but different protocols. Eur Rev Med Pharmacol Sci 2015; 19: 927-930. Review.

15. Hoffmann S, Papadopoulos N, Visel D, Visel T, Jost-Brinkmann PG, PRÄGER TM: Influence of piezotomy and osteoperforation of the alveolar process on the rate of orthodontic tooth movement: a systematic review. J Orofac Orthop 2017; 78: 301-311. https:// doi.org/10.1007/s00056-017-0085-1

16. Hoogeveen EJ, Jansma J, Ren Y: Surgically facilitated orthodontic treatment: a systematic review. Am J Orthod Dentofacial Orthop 2014; 145: S4 51-64. Review. https://doi.org/10.1016/j.ajodo. 2013.11.019

17. Joss-Vassalui I, Grebenstein C, Topouzelis N, Sculean A, Katsaros C: Orthodontic therapy and gingival recession: a systematic review. Orthod Craniofac Res 2010; 13: 127-141. Review. https://doi.org/ 10.1111/j.1601-6343.2010.01491.x

18. KIM Y, PARK JU, KoOK YA: Alveolar bone loss around incisors in surgical skeletal Class III patients. Angle Orthod 2009; 79: 676682. https://doi.org/10.2319/070308-341.1

19. Lee KB, Lee DY, Ahn HW, Kım SH, Kim EC: Roitman I. Tooth movement out of the bony wall using augmented corticotomy with nonautogenous graft materials for bone regeneration. Biomed Res Int 2014; 347508. https://doi.org/10.1155/2014/ 347508

20. Lee W, Karapetyan G, Moats R, Yamashita DD, Moon HB, FerGUSON DJ, et al: Corticotomy-/osteotomy-assisted tooth movement microCTs differ. J Dent Res 2008; 87: 861-867. https://doi. org/10.1177/154405910808700904

21. LUND H, Gröndahl K, Gröndahl HG: Cone beam computed tomography evaluations of marginal alveolar bone before and after orthodontic treatment combined with premolar extractions. Eur J Oral Sci 2012; 120: 201-211. https://doi.org/10.1111/j.1600-0722. 2012.00964.x

22. Mulie RM, Hoeve AT: The limitations of tooth movement within the symphysis, studied with laminagraphy and standardized occlusal fims. J Clin Orthod 1976; 10: 882-889.

23. Murphy KG, Wilcko MT, Wilcko WM, Ferguson DJ: Periodontal accelerated osteogenic orthodontics: a description of the surgical technique. J Oral Maxillofac Surg 2009; 67: 2160-2166. https:// doi.org/10.1016/j.joms.2009.04.124

24. Nagy $P$, Molnar B, Nemes B, Schupbach P, Windisch P: Histologic evaluation of human intrabony periodontal defects treated with deproteinized bovine bone mineral in combination with orthodontic tooth movement: a case series. Int $J$ Periodontics Restorative Dent 2019; 40: 321-330. https://doi.org/10.11607/prd.4346

25. Richmond S, Shaw WC, Roberts CT, Andrews M: The PAR Index (Peer Assessment Rating): methods to determine outcome of orthodontic treatment in terms of improvement and standards. Eur J Orthod 1992; 14: 180-187. https://doi.org/10.1093/ejo/14.3.180

26. SCHILling T, MüLleR M, Minne HW, ZiegleR R: Influence of inflammation-mediated osteopenia on the regional acceleratory phenomenon and the systemic acceleratory phenomenon during healing of a bone defect in the rat. Calcif Tissue Int 1998; 63: 160-166. https://doi.org/10.1007/s002239900508

27. Shah R, M G T, Thomas R, Mehta DS: An update on the protocols and biologic actions of platelet rich fibrin in dentistry. Eur $J$ Prosthodont Restor Dent 2017; 25: 64-72. doi: 10.1922/EJPRD 01690 Shah09

28. Wang B, Shen G, Fang B, Yu H, Wu Y, Sun L: Augmented corticotomy-assisted surgical orthodontics decompensates lower incisors in Class III malocclusion patients. J Oral Maxillofac Surg 2014; 72: 596-602. https://doi.org/10.1016/j.joms.2013.08.021

29. Wilcko MT, Wilcko WM, Pulver JJ, Bissada NF, Bouquot JE: Accelerated osteogenic orthodontics technique: a 1-stage surgically facilitated rapid orthodontic technique with alveolar augmentation. J Oral Maxillofac Surg 2009; 67: 2149-2159. https://doi. org/10.1016/j.joms.2009.04.095

30. ZADEH HH: Minimally invasive treatment of maxillary anterior gingival recession defects by vestibular incision subperiosteal tunnel access and platelet-derived growth factor BB. Int J Periodontics Restorative Dent 2011; 31: 653-660. 


\author{
NAGY P, PÖRZSE V
}

\title{
Preorthodontic corticotomy and simultaneous bone augmentation in the prevention of buccal alveolar dehiscences \\ Case presentation
}

Buccal orthodontic tooth movement (OTM) of the anterior teeth out of the osseous envelope of the alveolar process in case of front teeth crowding may be associated with a higher tendency for developing gingival recessions. The aim of this case report is to present the effectiveness of a minimally invasive preorthodontic corticotomy combined with a buccal bone augmentation according to the rules of periodontally accelerated osteogenic orthodontics (PAOO). The main goal of our therapy is to increase or maintain the buccal bone thickness, which could prevent the development of gingival recessions. Corticotomy possibly have an additional benefit throughout regional acceleratory phenomenon, reducing the duration of OTM in the early treatment phases. A generally and periodontally healthy individual at the age of 17 presenting crowding and thin bone morphotype in the mandibular y front area, who requiresting OTM with incisor proclination, was treated. Surgery was performed under local anesthesia. Three vertical incisions were performed on the midline and on both sides between lateral incisors and canines, with preservation of the papilla integrity. Incisions were connected by tunneling knifes in 2 layers, subperiosteally in the whole length and supraperiosteally apically from the mucogingival junction. Corticocisions were utilized by ultrasonic instrument penetrating through the cortical bone. "Sticky bone" plates, a combinations of platelet rich fibrin (PRF) and xenograft, were used subperiosteally for bone, and PRF membranes supraperiosteally for soft tissue augmentation. Initiation of OTM started 1 week postoperatively, and activation of the multibond appliance was performed activated in 2 weeks. The extent of tooth movement measured on the central incisor was compared followed-up on cephalometric radiographs made taken at the different treatment time appointments, while buccal bone thickness on the 6 front teeth was evaluated in CBCT before and after OTM. The alignment phase ended up at the 20th week due to an initial arch wire sequence using light forces. The buccal bony wall thicknesses showed similar values compared to the initial ones, and there was no radiologically proven substantial vertical bone loss. The presented comprehensive treatment approach promised a good option in the prevention of the periodontal side effects during orthodontic treatment.

Keywords: corticotomy, PAOO, bone augmentation, orthodontics, tooth movement, multibond 